Article

\title{
A DECENT HOUSE, A DECENT JOB, A DECENT LIFE: SOCIAL REPRODUCTION THEORY AND WORKING CLASS ORGANIZING IN CAPE TOWN
}

\author{
BY ADRIAN MURRAY \\ School of International Development and Global Studies, PhD Candidate \\ University of Ottawa
}

\begin{abstract}
While progressive coalitions continue to oppose neoliberal restructuring, organizing on the left remains fragmented and the underlying unity of the multitude of working class struggles undertheorized. Overcoming these theoretical and practical obstacles is an urgent task in the face of both renewed attempts by the state and capital to ensure stability and deepen market penetration into the remaining untouched corners of working-class life, and threats to unity generated within the left by narrow understandings of class and identity. Drawing on empirical research around struggles for housing and public services in Cape Town, South Africa, this paper argues that Social Reproduction Theory (SRT) may provide just such an integrated theorization of the diverse experiences and struggles of the working class. SRT recovers class by building from everyday experience to generate unifying understandings of class struggle within a capitalist totality in which difference within the class is constitutive.
\end{abstract}

\section{Keywords}

Capitalism; class; neoliberalism; social reproduction; social movements

\section{Introduction}

The turn toward austerity in the recent period of neoliberal capitalism has hit hard in working class communities across South Africa. Already struggling in vain for the better life promised to them after apartheid, South Africans have responded as the country has registered some of the highest protest levels in world over the last decade (Alexander et al. 2016). Despite these widespread mobilizations, the deteriorating material conditions of life in the new South Africa and the ideological management of this constant fracturing of the social by the state and capital has made it very difficult for a working-class consciousness, which relative to its ruling class opponents, "needs a larger segment of maturing time..., to emerge" (Bannerji 2016, 20). Various tropes are trotted out by the ruling class to rationalize the status quo: individual responsibility, the racialized other and immigrants, hidden or "third forces", the meddling of foreign powers, and the list goes on. Backed by the coercive arm of the state and in the context of the grind of everyday life 
under neoliberalism and its ongoing restructuring of society, the ruling class has been particularly effective in disabling working class organizing in the post-apartheid marriage of markets and democracy.

Since 2012, working alongside the Housing Assembly (HA), a social movement struggling for access to housing and public services in Cape Town, I have been witness to many of the disabling moves made by the state and capital. I have also become painfully familiar with two interconnected trends that stubbornly persist in progressive thought and action which serve to undermine the South African left from within while the vicious attacks continue from the outside. The first is a division between workers and the unemployed/community or between struggles at the point of production and those around reproduction and the valorization of one or the other. The second is a distinction between struggles around class and those around place (the "local" or "community"), autonomy, and identity which are, apparently, beyond class in various ways. While there have been important instances of these struggles coming together post-apartheid, they have remained relatively distinct in both theory and practice. While often asking important questions, these narratives are obstacles to working class unity and struggles across the length and breadth of society. In remaining at the level of historical appearances and addressing only partially the myriad struggles and experiences of working-class life, these narratives also contribute to the conscious or unconscious reproduction of capitalist social relations, and constitute a reproductive praxis, which undermines the very struggles they seek to augment.

In an effort to overcome the obstacles to organizing that these concepts create or exacerbate, in this article I draw on Social Reproduction Theory (SRT) and the praxis ${ }^{1}$ of the HA to argue for a reconceptualization or renewal of our understanding of working class struggle that takes seriously both the working class as it actually exists and the process of organizing it. In particular, I argue that SRT offers a theory and potentially informs a practice of class politics which is attentive to "the diverse forms of experiences in capitalist society" (McNally 2015, 139). Seeking not merely to understand the world but also to change it, SRT takes the diverse immediate needs and struggles of working-class experience as its point of departure in working towards broader social transformation. In what follows I suggest that the organizing work of the HA in Cape Town is well captured by SRT and is an example of a revolutionary praxis in the process of becoming. Taken together, SRT and HA praxis offer a more adequate theorization of struggles beyond the workplace as class struggles within a capitalist totality, rather than merely gesturing at their relationship to workplace struggles, and a way to convert these understandings into practice.

The first section of this paper briefly establishes a critique of the limited conceptions of class identified above while the second situates the discussion in the South African experience. The third section draws on SRT to develop an alternative understanding of class which sees struggles beyond the workplace around social reproduction and inclusive of those against oppression as class

\footnotetext{
${ }^{1}$ Marx's "theory of consciousness was actually a theory of praxis, i.e., a theory of the inseparable unity of thought and practice rather than a sequential theory of praxis" (Allman 2007, 33-34).
} 
struggles. Informed by this analysis the fourth section explores HA organizing in Cape Town while the final section considers the implications of this analysis moving forward.

\section{(mis)Understanding Class}

The global working class has long faced accusations that it has failed to overthrow capitalism due to its inability to present a serious challenge to the intensification of exploitation and oppression in the neoliberal era. Today it is derided as irrelevant and its historical position as privileged agent of social transformation widely rejected. As a result, "[o]ther candidates-women, racial/ ethnic minorities, new social movements, an amorphous but insurgent "people," or community, to name a few-are all thrown up as possible alternatives to this presumed moribund or reformist or masculinist and economistic category, the working class" (Bhattacharya 2017, 68).

The privileging of the "local", the "community" and identities "beyond class" in a vague notion of "the people" or "the poor" at one end of the spectrum, and of the formal worker, worker organizations and political parties at the other, however, are indicative of understandings of social struggle that either dispense with class entirely or hang onto it in an exceeding narrow way, whether in theory or practice. David McNally $(2015,143)$ sums up the problematic nature of these distinctions very well, arguing that:

where class fanaticism refuses the rich narratives and struggles essential to genuine anti-racism, socialist-feminism and queer liberation, to take three examples, and in so doing posits class in the form of abstract universality, the politics of personal identity commit a parallel reification of the particular, refusing to acknowledge its internal relations with all the partial totalities that compose the social whole.

Both fail to take class seriously, or at least they do not take the experience of the working class as it actually exists seriously. As Bhattacharya (2017, 68, emphasis in original) notes:

What many of these condemnations have in common is a shared misunderstanding of exactly what the working class really is. Instead of the complex understanding of class historically proposed by Marxist theory, which discloses a vision of insurgent working-class power capable of transcending sectional categories, today's critics rely on a narrow vision of a "working class" in which a worker is simply a person who has a specific kind of job.

While both perspectives directly address the working-class experience - the wage relation, oppressions of various kinds, many of the diverse experiences of life under capitalism - they do so partially. Rather than being experienced partially, however, as Himani Bannerji $(2005,144)$ argues, 
people's "sense of being in the world, textured through myriad social relations and cultural forms, is lived or felt or perceived as being all together and all at once."

While theory does not instrumentally dictate practice (see Allman above), it does inform it. It follows that theory that reifies these hived off, common sense understandings of experience contributes to reproducing the fragmentation of working class communities engendered by the ongoing material and ideological assault of neoliberal capitalism and struggles against it (Choudry 2015). As Bannerji puts it (in Coburn 2012, 9):

Theory cannot do less, if it does not want to engage in a misleading fragmentation of actual experience. The problem is at once conceptual and political: conceptual since it reifies as separate objective "fragments" what are unified social experiences and political since this fragmentation is then reproduced in strong distinctions between communities and movements, that then have difficulty accomplishing unified political action.

As society has become increasingly exposed to the vagaries of the market over the last several decades of neoliberalism, a chasm of sorts opened up between "old social movements (OSMs)...[unions, parties] considered to advance working-class-based, social democratic or socialist political projects, while new social movements (NSMs) are considered to advance nonclass-based or cross-class-based political projects oriented toward identify formation or autonomy" (Holst 2011, 119). Despite the proliferation of narrow issue-based organizing, some of the strongest successes in terms of working class organizing in this period have been alliances and coalitions built between and among these movements. Dubbed Social Movement Unionism (SMU) in the labour literature, these alliances challenge the separation of "new" and "old" social movements (Spronk and Terhorst 2012).

\section{Social movements and working-class fragmentation in South African}

Building on the rich experience of organizing and the deep alliances between workers and communities in the fight against apartheid-itself partial inspiration for the development of SMU as a concept and strategy - there has been consistent mobilization in South Africa since the mid1990s in opposition to the neoliberal political economic trajectory of the post-apartheid era. Independently and in coalition, unions and so called "NSMs" dominated by community organizations have fought, with varying degrees of success, the privatization and corporatization of public services, casualization and restructuring in the workplace, and the dispossession and eviction of working class South Africans from their homes and land (McDonald and Pape 2002; Ruiters 2014). These alliances have lacked the organic strength of anti-apartheid coalitions, however, having lost their "Political independence... when the majority of both labour and community movements, in the form of the Congress of South African Trade Unions (COSATU) 
and the United Democratic Front (UDF), entered into formal alliances with the dominant political forces of the liberation movement, the African National Congress (ANC) and the South African Communist Party (SACP)" (McKinley 2016, 60). The "NGOization" of community movements and the institution of a neoliberal corporatist labour regime also "served to increase the social distance between (employed) workers and (unemployed/informalized) poor communities. "Free market" forces and an individualist, work-defined citizenship became the change-agents of both social and political relations of the broad working class" (McKinley 2016, 60). Meanwhile the ANC state has pursued a vigorous campaign to characterize these formations as marginal and extremist, frequently deploying the coercive apparatus of the state against them. The result was a distancing of COSATU unions from their community partners and the general decline of the latter and protest levels by the mid-2000s.

Community protest has since reignited though it has been less focused and fragmented with the few formal organizations largely unable to tap into popular anger and discontent (Hart 2014). Key players in earlier alliances, like the South Africa Municipal Workers Union (SAMWU), have been notably absent in these protests, despite leading the largest public sector strikes in South African history in 2007 and 2010 (Ceruti 2011). Strikes have intensified in the mining sector in the wake of the 2012 Marikana Massacre, where, following a wildcat strike by workers in the platinum belt, 34 miners were killed by police on August 16. The strike wave that followed spilled over into the agricultural sector (Webb 2017) and in 2015 the largest strike in South African history saw 70 000 mineworkers walk off the job for five months. Later that year the \#FeesMustFall student movement spread across the country, shutting down campuses and demanding free, decolonized education and an end to outsourcing on campuses, mobilizations which have continued albeit less intensely (Ashman et al. 2017).

While there have been many hopeful instances of working-class unity forged in and through these struggles, they have largely remained temporary and informal. Arguably the most notable recent effort to build unity was the establishment of the United Front (UF) by the National Union of Metalworkers of South Africa (NUMSA). Following the Marikana Massacre a series of events unfolded which saw the departure of NUMSA, the largest union in South Africa, from the ANC alliance and the eventual launch of the UF, to "coordinate struggles in the workplace and in communities" (NUMSA 2013) along similar lines to the UDF that fought apartheid in the 1980s. Several years later, however, the record and trajectory of the UF remains questionable (Paret 2017; Ashman et al. 2017). While its organizing work has been geographically uneven, early on the UF ultimately devolved into a bureaucratic initiative to facilitate political discussion and in some regions degenerated into a mobilizing device for what was a very poor showing in the 2016 local government elections. According to HA organizers, the UF has had very little grassroots engagement with working class communities and movements in Cape Town and has a dismissive attitude towards broader working class organizing and rank-and-file worker and community participation. When the UF has engaged, its role is marginal or attempts to subsume broader working class struggles under those of organized labour; what many organizers call "rent-a-crowd" tactics. Though in the immediate aftermath of NUMSA's departure from COSATU, it was far more 
radical than other unions in the country, it appears to have reverted to a patriarchal, bureaucratic form of unionism based on a narrow reading of Marxist-Leninism akin to that of the SACP (Pillay 2017). There is a growing body of evidence for this assertion in NUMSA's reorientation away from rank-and-file worker education and the facilitation of economic, ecological and gender justice and towards the new South Africa Federation of Trade Unions (SAFTU) founded in 2017, and the poor showing of the hastily established Socialist Revolutionary Worker's Party (SRWP) in the 2019 national elections (Ashman et al. 2017; Nassen-Smith 2018; Pillay 2017).

At first glance, it may appear that these divisions within the working class reflect the social distance between the objective class positions of unionized workers and the under/unemployed amidst growing flexibilization and casualization. Upon closer examination of workers' living conditions, particularly their access to housing and services, it appears that the experience of these seemingly divergent sections of the working class is far more similar than their employment status suggests (Paret 2017). What appear to be greater obstacles to unity are broadly held understandings of class and class struggle and the forms of organizing and tactics they inform. The neoliberal corporatist post-apartheid labour regime, the bureaucratization of unions and a move away from shop-floor organizing have institutionalized labour struggles to a large degree, whereas community protests are more loosely organized at the local scale and highly disruptive. Relatedly, Alexander and Pfaffe $(2013,2)$ argue that, "In a sense, for the poor, the capitalist lies beyond the state, and for workers, it is the other way around" the latter seeking higher wages from their employer, and the former better services from local government. These appearances obscure the ways the neoliberal restructuring of both production and social reproduction serve "capital in general", elaborated below, regardless of whether the immediate opponent is the state or capital (Lebowitz 2003). The wildcat strike in Marikana, the subsequent rise of organizing around advice offices and workers forums (see the Casual Workers Advice Office, Simunye Workers Forum), and efforts by organized community formations and emergent coalitions to contest the commodification of social reproduction, however, provide evidence that these divisions are not insurmountable (Ngwane 2017; Pillay 2017; McKinley 2016).

As this brief review shows, struggles around production and reproduction have remained relatively distinct in South Africa in terms of consistent organizing. Although there are a number of factors beyond working class control that are implicated in its fragmentation there are also those that serve to undermine it from within. These include explicit and implicit understandings which separate struggles around production and social reproduction, those waged by workers and those waged by the unemployed, in which distinctions between locality/autonomy/identity and an abstract economistic notion of class are pronounced. Though often occluded from analysis of social struggle in South Africa, patient organizing to overcome these divisions continues. The following theoretical insights furnished by SRT inform the argument that these efforts may present alternatives to overcome this divide. 


\section{Social Reproduction Theory}

Perhaps SRT's most important theoretical contribution, among many, is its point of departure: the production of the commodity labour power. According to SRT, social reproduction includes "all those... processes involved in maintaining and producing people... and their labour power on a daily and generational basis" (Bezanson and Luxton 2006, 3). Beginning not from the perspective of capital but from labour, and specifically from working class experience, helps to rectify the capitalocentric vision of capitalism that dominates both narrow understandings of class and those that deny the utility of the category altogether. While Marx's conception of production in the Grundrisse, Capital and elsewhere, included the reproduction of labour (Sayre 2008; see also Lebowitz 2003; Anderson 2010), gesturing at their underlying unity, he left the latter more or less untheorized focusing primarily on capital (Ferguson 2016; Bhattacharya 2017). While many have drawn attention to this relation perhaps the most common illustration is through spatial metaphor: the sphere or space(s) of production on the one hand and a sphere or space(s) of reproduction on the other, maintaining their distinction. While roughly corresponding to the formal appearance of society-the workplace on the one hand and the home/community on the other-larger institutions like schools and hospitals and those whose labour cuts across these spaces like domestic workers (Davis 1981), have long blurred this neat distinction. SRT has picked up on this theoretical gap arguing as Bhattacharya (2016, n.p.) does that if "the spatial separation between production and reproduction is a historical form of appearance then the labour that is dispensed in both spheres must also be theorized integratedly." In other words, given the centrality and unique characteristics of the commodity labour power to capitalism, "it is not enough to add the process of social reproduction of labour to the economic analysis: it is necessary to define the particular relationship that links production and reproduction" (Picchio in Luxton 2006, 36).

Integrating production and social reproduction, SRT conceives of class struggle as unfolding within the broader social totality of capitalism through which all variety of social relations are integrated (Ferguson 2016). The separation of workers from the means of production under capitalism necessitates wage labour which constitutes workers' primary means of reproduction. It follows then that the commodities purchased with the money provided by wages are not merely articles of consumption they are also, in combination with public goods, the means of production of the commodity labour power. Lebowitz (2003) contends that the production of the commodity labour power constitutes a "missing circuit of wage labour", not present in Marx's work, which takes place outside of the formal circuit of production but remains essential to it. In this circuit, the worker undertakes "a process of self-transformation" (Bhattacharya 2017, 81 emphasis in original) not for the purposes of capital but for their own self development, which goes far beyond simple biological reproduction to also encompass social needs. At the same time capital pushes in the opposite direction, exerting downward pressure on wages to capture more 
surplus value from gains in productivity for example, among other strategies within and beyond the workplace. This is a contradictory process, however, as capital simultaneously requires workers to consume and satisfy their needs through the purchase of more and new commodities in the market to realize value. In other words, the goal of "the worker's own need of development" (Marx in Bhattacharya 2017, 82) is frustrated by the reality that capitalism

exists for the valorization of capital and not the social development of labour. Thus the worker, due to the very nature of the process, is always-already reproduced as lacking in what she needs, and hence built into the fabric of wage labor as a form is the struggle for higher wages: class struggle.

The key argument made by SRT in this regard is that although wages form the primary basis of reproducing workers under capitalism, the reproduction of labour power and struggles over it are much more expansive and include contests over the provision for workers' needs across society. As aforementioned, this includes access to water, sanitation, housing, public transportation, childcare, education, healthcare, pensions and a host of other public services. Moreover, the "needs" of workers are not natural or constant but are themselves relative and determined socially, such that the standard of necessity at which workers are reproduced is "enforced by class struggle" (Lebowitz in Bhattacharya 2017, 79). This is not only the case when it comes to the level of wages and the commodities they can purchase but also the level of social wage and the amount and schedule of time outside the workplace available to "enjoy" these goods.

The common understanding that social reproduction appears to take place beyond capital or free from its influence is thus questionable upon closer examination. The power of "capital in general" transmitted through the state, the market, institutions like schools and hospitals and through social relations more broadly, conditions the production of the commodity of labour power and is central to the extraction of surplus labour at the point of production and its realization (Bhattacharya 2017). Thus, while the production of labour power has historically been confined to the family and the community, these functions are not beyond the reach and influence of capital. Rather they are impacted by capital indirectly, through the state and other institutions that reflect the balance of class forces in society and through capitalist social relations more broadly, increasingly so in the context of the intensification of market penetration into spaces of everyday life.

What's more, there is no abstract capitalism in the sense that narrowly economistic understandings of class often suggest. Rather, there is only concrete capitalism which "critically depends upon the messy, complex, set of lived relations carried out by differently gendered, sexualized, racialized human beings" (McNally and Ferguson 2015, n.p.). SRT offers critical insight into perceptions of difference within the working class and of struggles, often associated with New Social Movements and struggles to end particular forms of oppression, that many have argued are "beyond class." As Raymond Williams observed in the context of Thatcherite England, just because they often emerge outside of the workplace and organized labour has failed to take up struggles 
around race, women's rights, poverty, housing and public services, peace, the industrial contamination of the environment, and so on, this does not mean that these struggles are somehow beyond class. Rather, it is working class people who have the most to gain from such struggles argued Williams (in Bhattacharya 2017, 88): "there is not one of these issues which, followed through, fails to lead us into the central systems of the industrial-capitalist mode of production and... into its system of classes." This is not to privilege class but rather to insist that "so long as certain oppressive forms of relations facilitate (rather than hinder) the task of bringing laborpower to capital's doorstep, there will be powerful forces sustaining racism, sexism and other oppressions - and discouraging alternative forms of human relations" (McNally and Ferguson 2015, n.p.).

If the "realm of freedom" of the worker, the "space" outside the point of production, must still conform to the "temporal and objective necessities of other social relations," specifically those of capitalism, then the struggle over this realm represents a struggle against capital in general, as opposed to those in the workplace which target specific or many capitals (Bhattacharya 2016, n.p.; Marx 1981, 958-959). Again, this is not to privilege struggles around social reproduction over those at the point of production but to situate all struggles for human emancipation within the totality of capitalist social relations of production and reproduction which "are actually a concatenation of existing social relations, shaped by past history, present institutions, and state forms" (Bhattacharya 2017, 87) and are organized according to gender, race, and sexuality among other social relations. Developing this integrative analysis is not just a descriptive or analytical exercise. Rather, as Meg Luxton (2006, 36-37) argues, "it allows for an explanation of the structures, relationships, and dynamics that produce those activities" and provides some tools for contesting them.

\section{Organizing around Social Reproduction in the Cape Flats}

Beginning with their mutual point of departure-working class experience-in what follows I will suggest that the praxis of the HA in Cape Town is well captured by SRT. Through productive engagement with movement praxis, SRT's integrative theorization of production and reproduction within a capitalist totality can offer much to this organizing effort and has the potential to contribute to the vital task of building working class unity. Further to this, the HA's work represents a potential alternative to the fragmented reproductive praxis prevalent in organizing on the left in South Africa which, although limited in scope and magnitude and constantly under threat from both within and without, is a concerted project with the aim of developing a critical, revolutionary praxis to organizing around social reproduction.

The HA is a coalition of community organizations primarily from Cape Town and the surrounding area engaged in struggles for housing and related public services. The organization was officially founded in 2012 by a group of activists and organizers who had been coming together for many years following the aforementioned decline of an earlier wave of more organized social movements in the mid 2000s via popular education programs run by a local non-governmental 
organization, the International Labour Research and Information Group (ILRIG). The HA seeks to challenge, both materially and ideologically the conditions of everyday life for the working class under neoliberal capitalism and to engage in the process of building alternatives.

This effort begins with the patient work of organizing from house to house and street to street, bringing together the many diverse working-class experiences around housing and public services. This organizing takes place primarily on local terrain engaging with households, communities, the state and capital. This work includes popular education, research, writing and propaganda production, along with the no less important collective amelioration of living conditions and both local and more generalized direct action around poor housing and service delivery. The HA has also led coalition building efforts with unions, including SAMWU, NUMSA, the United Front and the Food and Allied Workers Union (FAWU) and with other worker and community formations from the provinces of Gauteng and KwaZulu Natal including the Simunye Workers Forum and Abahlali baseMjondolo. In 2017 the HA held an independent Political School which brought together community activists and organizers from around South Africa along with worker and student leaders (unprecedented in recent past) to discuss, debate and organize a national campaign for "Decent Housing for All" premised on organizing work in communities across the country. The school was followed up by a coordinated national day of action to facilitate this local organizing and raise consciousness in the spaces of working-class life. Most recently, the HA has played an important role in the Cape Town Water Crisis Coalition (CTWCC), formed to contest the thoroughly neoliberal response to the ongoing water crisis and held its second annual Political School in March 2018.

Rather than merely seeking to secure the simple amelioration of poor housing and service delivery, and thus remain mired in the immediacy of the everyday, HA organizing engages with the daily experience of working-class households and communities in an effort facilitate critical reflection, self-organization and action. SRT concurs, as "situating labor-sensuous, practical activity in both its alienated and nonalienated forms - as the starting point of social theory (instead of structures and functions), foregrounds the experiential and human agency" (Ferguson 2008, 50). This approach is not taken because experience "is a repository of truth... [but because] experience is key to constructing - and understanding - consciousness, since it is through experience that individuals interpret or make sense of, the world" (Bannerji paraphrased in Ferguson 2008, 47). Rendering consciousness critical is at the core of overcoming both the ideological and material effects of neoliberal capitalism and its powerful ability to fragment working class struggle.

The opportunity for reflection, organizing and action is also crucial as the reality of daily life under neoliberal capitalism means "that few people have sustained, positive experiences of collective decision making, socialized resource allocation, or solidaristic, noncompetitive environments in which to work, learn, or play" (Schein 2014, 173). This is reflected in the perception that the working-class in Cape Town does not 
understand exactly what is wrong as a collective. We are suffering as a collective, but we are fighting as individual households. Even family by family, one member to one member, competing for jobs, competing for my family instead of seeing this as a social problem (Organizer C, April 2016).

This atomization and the intensification of competition amidst manufactured scarcity throws up enormous obstacles to the organizing process both in how working-class communities understand their circumstances and in the practicalities of struggle so that divisions abound based on "racism, sexism, no jobs, our own issues... people are struggling to survive” (Organizer A, November 2015). David McNally $(2011,149)$ refers to these impacts of neoliberalism as "molecular transformations at the most basic levels of everyday life" which serve to disrupt socio-material solidarity and collective subjectivity. The link between state policy, these conditions and organizing is clear:

People's conditions are an obstacle, the austerity and the neoliberal policies, it's almost like it lessens people's energy. People want to organize but these policies and the things that happen to us every day... Positively it's the basis of wanting to organize but negatively its puts you down all the time. You know you are in real need of water and it's getting worse. You become despondent. You know those people that struggled for the ANC then [during apartheid], they are tired of struggling so why must I struggle again. It's just getting worse and it's not going to change... (Organizer B, November 2015).

This policy trajectory and the state and capital's material and ideological onslaught in South Africa, especially when it comes to social reproduction, is brutal, individualizing and demoralizing despite considerable expenditure on "free basic services" and a large social grant system (for a detailed analysis of these dynamics see Ruiters 2016 and Hart 2014). In Cape Town these pressures have intensified as the city struggles to cope with a drought and water shortage that reached crisis levels in late 2017. The response to the crisis has included the stepped-up installation of Water Management Devices (WMDs) which dispense 350 litres of water daily before cutting off household water supply. While poor households are generally encouraged to accept a WMD, all households with monthly water consumption above 10500 litres are now required to have such a device installed (CoCT 2018). This policy has enormous implications for overcrowded workingclass households in both the short-term, as they disproportionately suffer restricted access and escalating water bills as the shortage worsens, and in the longer-term as water commodification becomes normalized out of the "necessity" of managing the crisis through restrictions, rising rates and WMDs.

In both the disciplinary discourse and practice of the privatization and commodification of social reproduction the responsibility for water cut-offs and shortages, among other indignities, is placed directly on the shoulders of working-class families. This has a deeply fracturing impact as one HA organizer argues "we've gone from communities to individuals. That's what 
neoliberalism has done to us" (Organizer A, November 2015). HA praxis renders critical this experience of housing, service delivery and employment at the "sensuous level of everyday life" through a collective process of using experience to build a critique of the political economy of neoliberal capitalism which challenges the demoralizing and individualizing material and ideological onslaught of the state and capital. This critique wholeheartedly rejects both the dominant and "common sense" perspectives, locating the responsibility for the current state of affairs in the "failings of the government's neoliberal housing policy" arguing that "cheap policies such as site-and-services, the upgrading of informal settlements and backyard dwellings, 'reblocking' initiatives, and self-help schemes... are hopelessly inadequate changes and unacceptable as alternatives to decent housing for all.” The movement locates organizing as part of building a "mass organization that unites the working class... to especially reach out to and mobilise... disadvantaged and oppressed groups... [and] link up with international struggles... to develop a working-class alternative to the neoliberal capitalist housing policy framework" (HA 2014, n.p.).

In addition to the atomizing effects of neoliberal restructuring, HA organizers are adamant that the state and capital have been enormously effective in dividing working-class communities more directly. While patronage is a glaring feature of South Africa politics with parties vying for support particularly around election time (a disruptive and fragmenting force beyond the scope of this paper) the apparatus of the local state has also played a role in exacerbating tensions and divisions, particularly along racial and ethnic lines and especially in the poor management of public services post-1994 (McDonald 2008). In efforts to amalgamate several waiting lists and apply a non-racial housing policy to a society stratified by apartheid, a process of housing allocation and service delivery has emerged which appears to favor some over others, lacking the impartiality with it was originally conceived (Levenson 2017; Oldfield and Greyling 2015). This is the case whether intentional-the common perception-or merely a circumstance of the competitive process of housing allocation in the context of budgetary constraints, private sector dependent delivery mechanisms and demand that vastly exceeds supply. In this context racial and xenophobic explanations of why housing and services are being delivered to some and not others find fertile ground and are counterproductive to challenging the policy trajectory of the state (Patel 2015). For one organizer (Organizer B, November 2015), HA work is vital to the process of overcoming these divisions, not by making statements for racial harmony or through reconciliation activities infused with the nationalism of the post-apartheid "Rainbow Nation" but by "working in... communities, going around and collecting peoples' demands, speaking to them about their issues, relating to their issues in their own comfortable space [because we] are in the same situation and I'm relating with your issues and the importance of why we need to stick together..., as the working class." In thinking through this lived experience, knowledge and understandings formed by HA organizers through hard conversations about gender, race and class and what freedom really means in the "new" South Africa, are at the core of developing a relevant critique of capitalist social relations vital for building solidarity and strong working-class movements. 
The relevance of this critique to overcoming diversity within the working class was profoundly felt in a successful short-term alliance in 2015 between the HA, struggling around water cut-offs in communities, and unionized workers, striking around wages and working conditions, in which gender, race, and class differences loomed large. Through a process of doorto-door campaigning and political education workshops, HA organizers helped to address the reality:

that workers and communities still find it difficult, even... [with the alliance] during the strike... to see the link. It wasn't difficult for [us]... because we've come through the stage of being conscientised, talking about the issues... I'm living in the community before I became a factory worker... [the] community needs to support workers because that is our people in the community. They come home and their electricity has been cut, they are living in the backyards, so they also have [housing] waiting issues... it's one big thing that needs to come together. And... one of the things we've learned out of the strike is that we need political education. Now is the time more than ever... people need to understand that we need to bring the two together. (Organizer D, March 2016).

As one incensed HA member put it, reflecting on the common experience of workers and community members (often unemployed) and the relationship between the state and capital that was generalized through the alliance over the course of the strike: "die munisipaliteit is die baas en die baas is die munisipaliteit [the municipality is the boss and the boss is the municipality]" (Focus Group B, March 2016).

Informed by its critique of the political economy of housing and public services and with the explicit goal of proposing working-class alternatives to the neoliberal status quo, the HA's approach is summed up well by Ferguson (2016, 57 emphasis in original) when she argues from the perspective of SRT that "Any struggle within the realm of social reproduction - be it anti-racist, feminist, anti-colonial, or be it over education, healthcare, transportation - that promotes human need over capital's interests can chip away at the capitalist social formation." In the alliance above, a HA organizer (Organizer D, March 2016) emphasized the importance of social reproduction and its gendered experience, adamant that:

It was the women that led the strike. The expectation would have been after 6 weeks women will start saying 'but listen I have a family can we not negotiate, can we not stop the strike?' But women were saying 'let us go forward'! It's the woman that says I can't go to work today because I need to take my child to the clinic... it's women that have been on the waiting list for 20,35 years and there are no houses for them... It's the mother that goes to the factory that must go home and work at the end of the day. It's the mother that needs to go to the municipality and beg the official, 'can you please, can I negotiate with my little wage, can you please put on my 
electricity'? It's the mother... that gets on the truck at 5 o'clock to go to the farm, to go and work and doesn't see her... household for the whole day. So for me it was important that women need to see that look this is affecting my life... now is the time for women to get much better organized because they are the people being affected at the end of the day.

The collective act of critically reflecting upon experience, organizing and taking action constitutes a learning process of "getting our humanity back" according to one HA organizer Organizer B, November 2015). The outcome of this learning process is more than just the sparking of critical consciousness, the development of abstract solidarity, organizational membership growth or coalition building. Rather, it also manifests in solidarity in action around the refusal of WMDs, evictions and land invasions, in coping with commodified service delivery including collective provisioning, and contesting the policy process including demands for improvements and increases to housing and service allocations. In other words, it is a process of transforming the immediate experience and future horizon of working class social reproduction in Cape Town and beyond.

\section{Conclusion}

For at least two interrelated reasons, informed by SRT, this paper argues that we draw our attention to understanding and engaging with and in the patient work of organizing carried out by social movements like the HA. Organizing which, rather than adopting the narrow, elite-driven and mobilization-focused praxis of many movements fetishistic as they are of organizational form or ideology, engages in the processes of building solidarity from working class experience to confront capitalist social relations.

The first points to SRT's argument, evident in the HA's praxis, that struggles beyond the workplace hold the potential to challenge, disrupt and overturn capitalist social relations. Struggles around housing and public services like those explored above, directly confront capital's efforts to privatize social reproduction and represent the seeds of an alternative which seeks to (re)appropriate and (re)collectivize "the means of subsistence for all" (Ferguson 2016, 57). It would appear that the body of evidence to support this line of argument is growing as capital's efforts to privatize social reproduction, and those of the state in its service, continue to intensify. As this mutual cooperation becomes increasingly visible (Wood 2009) divisions between struggles around production and social reproduction become less and less tenable. Struggles around public services like those in South Africa, particularly in the context of crises like the current Cape Town water crisis, are exemplary, simultaneously offering opportunities to organize and build working class consciousness and movements in the process.

The second, is that a host of oppressive social relations "are integral to and determinant of [capitalism]- in the sense that they really and actively facilitate- actual processes of capital 
dispossession and accumulation" (McNally and Ferguson 2015, n.p.). This means that struggles against racism, sexism, and colonialism, among others, are potentially struggles against capitalism. This includes struggles by differentially produced sections of the working class to secure access to the means of social reproduction. Thus "[i]nsofar as the internal relation of all oppressions with each other and with the capitalist totality is politically highlighted, such struggles can advance a class (as opposed to sectoral) consciousness, an awareness of the unity of the diverse relations that produce capitalism and society" (Ferguson 2016, 57). This is not a given however, as the preceding quote and HA organizing make clear. Rather, the potential of building a future that is socialist, anti-racist, feminist, queer-positive and so forth, lies in the process of collective struggles waged across the length and breadth of capitalist society.

Together these arguments emphasize the necessity for the patient work of organizing, of the sort practiced by the HA, which takes the sensuous experience of everyday working-class life as a starting point to spark critical consciousness and build broad working-class movements. The HA's praxis, well-illustrated by SRT, considers the struggles of households and communities around social reproduction to be valid, and indeed urgent, class struggles against "capital in general." This does not mean that all contemporary movements around social reproduction are manifestations of a working class for "its own self-development" but rather that within these struggles lies this incipient potential, one which can only be realized through struggle. As E.P. Thompson $(1978,149)$ remarked in describing class as both process and relation, "Class and classconsciousness are always the last, not the first, stage in the real historical process." SRT helps us to theorize this real historical process and the importance of struggles around social reproduction which, while they may be relatively invisible, like much of the work of social reproduction more generally, may prove to be an indispensable source of working class power in the future.

\section{Acknowledgments}

The author would like to thank Susan Spronk and Susan Ferguson for comments on an earlier version of this paper. This research was supported by the Social Sciences and Humanities Research Council of Canada.

\section{References}

Alexander, Peter, Trevor Ngwane, and Carin Runciman. 2016. "South Africa's rebellion of the poor." In III International Conference Strikes and Social Conflicts: combined historical approaches to conflict. Proceedings, edited by Martí Marín Corbera, Xavier Domènech Sampere and Ricard Martínez i Muntada, 148-161. Barcelona: CEFID-UAB. 
Alexander, Peter and Peter Pfaffe. 2013. "Social Relationships to the Means and Ends of Protest in South Africa's Ongoing Rebellion of the Poor: The Balfour Insurrections." Social Movement Studies: 1-18.

Allman, Paula. 2007. On Marx: An Introduction to the Revolutionary Intellect of Karl Marx. Rotterdam: Sense.

Anderson, Kevin B. 2010. Marx at the Margins. Chicago: University of Chicago Press.

Ashman, Sam, Zachary Levenson, and Trevor Ngwane. 2017. "South Africa's ANC: The Beginning of the End?" Catalyst 1(2):75-106.

Bezanson, Kate and Meg Luxton. 2006. Social Reproduction: Feminist Political Economy Challenges Neoliberalism. Montréal: McGill-Queen’s University Press.

Bhattacharya, Tithi. 2017. "How not to skip class : Social Reproduction of Labour and the Global Working Class.” In Social Reproduction Theory: Remapping Class, Recentering Oppression, edited by Tithi Bhattacharya, 68-93, London: Pluto.

Bhattacharya, Tithi. 2016. "The Ontology of Labour Power: Producing and Social Reproducing Capital." Presentation at Historical Materialism London, November $10^{\text {th }}$.

Ceruti, Claire. 2011. "The hidden element in the 2010 public-sector strike in South Africa." Review of African Political Economy 38 (127): 151-157.

Choudry, Aziz. 2015. Learning Activism. The Intellectual Life of Contemporary Social Movements. Toronto: University of Toronto Press.

City of Cape Town (CoCT). 2018. Water Outlook Report. Cape Town: CoCT.

Coburn, Elaine. 2012. “Thinking About Class, Race, Gender: Himani Bannerji and GA Cohen on Capitalism and Socialism." Socialist Studies 8 (1): 1-19.

Davis, Angela. 1983. Women, Race and Class. New York: Vintage Books.

Ferguson, Susan. 2016. "Intersectionality and Social-Reproduction Feminisms." Historical Materialism 24 (2): 38-60. 
Ferguson, Susan. 2008. "Canadian Contributions to Social Reproduction Feminism, Race and Embodied Labour." Race, Gender \& Class 15 (1-2): 42-57.

Hart, Gillian. 2014. Rethinking the South African Crisis: Nationalism, Populism, Hegemony. Pietermaritzburg South Africa: UKZN Press.

Holst, John. 2011. "Frameworks for understanding the politics of social movements." Studies in the Education of Adults 432: 117-127.

Housing Assembly. 2014. What the Housing Assembly Stands For. Cape Town: HA.

Lebowitz, Michael A. 2003. Beyond Capital: Marx's Political Economy of the Working Class, Basingstoke, UK: Palgrave Macmillian.

Levenson, Zachary. 2017. "Precarious welfare states: Urban struggles over housing delivery in postapartheid South Africa." International Sociology 32 (4): 474-492.

Luxton, Meg. 2006. "Feminist Political Economy in Canada and the Politics of Social Reproduction." In Social Reproduction: Feminist Political Economy Challenges Neoliberalism, edited by Kate Bezanson and Meg Luxton, Montréal: McGill-Queen's University Press.

Karl Marx. 1991. Capital, Vol III. New York: Penguin.

McDonald, David. A. 2008. World City Syndrome. New York: Routledge

McDonald, David A. and John Pape. 2002. Cost Recovery and the crisis of service delivery in South Africa. Pretoria: HSRC Press.

McKinley, Dale T. 2016. "Ships Passing in the Dark? Reigniting Labour-Community Alliances for Public Services in South Africa." In Making Public in a Privatized World: The Struggle for Essential Services edited by David A. McDonald, 59-80, London: Zed Books.

McNally, David. 2015. "The dialectics of unity and difference in the constitution of wage- labour: On internal relations and working-class formation." Capital and Class 391: 131-146.

McNally, David. 2011. Global Slump: the Economic and Politics of Crisis and Resistance. Oakland: PM Press. 
McNally, David and Susan Ferguson. 2015. "Social Reproduction Beyond Intersectionality." Viewpoint Magazine, 5.

Ngwane, Trevor. 2017. “The 'Spirit of Marikana' and the Resurgence of Working-Class Movement in South Africa." In Urban Revolt: State Power and the Rise of People's Movements in the Global South, edited by Trevor Ngwane, Immanuel Ness and Luke Sinwell, n.p., Chicago: Haymarket.

National Union of Metalworkers of South African (NUMSA) 2013. NUMSA Special National Congress, December 17-20: Declaration.

Oldfield, Sophie and Saskia Greyling. 2015. "Waiting for the state: a politics of housing in South Africa." Environment and Planning A 47: 1100-1112.

Paret, Marcel. 2017. "Working-class fragmentation, party politics, and the complexities of solidarity in South Africa's United Front.” The Sociological Review 652: 267-284.

Patel, Kamna. 2015. "Sowing the seeds of conflict? Low income housing delivery, community participation and inclusive citizenship in South Africa." Urban Studies: 1-20.

Pillay, Devan. 2017. "Trade union revitalisation in South Africa: Green shoots or false dawns?" Global Labour University Working Paper 5 Berlin: GLU.

Ruiters, Greg. 2016. "The Moving Line Between State Benevolence and Control: Municipal Indigent Programmes in South Africa." Journal of Asian and African Studies: 1-18.

Ruiters, Greg. 2014. "Spaces of hope: rethinking trade union-community alliances and citizenship in a post-alliance era in South Africa." Politikon 41 (3): 421-441.

Sayre, Nathan F. 2008. "Assessing the Effects of the Grundrisse in Anglophone Geography and Anthropology.” Antipode 40 (5): 898-920.

Schein, Rebecca. 2014. "Hegemony Not Co-Optation: For a Usable History of Feminism." Studies In Political Economy 94 (Autumn): 169-176.

Spronk, Susan. and Phillip Terhorst. 2012. "Social Movement Struggles for Public Services. In Alternatives to privatization: Public options for essential services in the global South, edited by David McDonald and Greg Ruiters, 133-156, New York: Routledge. 
Thompson, Edward. P. 1978. "Eighteenth-Century English Society: Class Struggle Without Class?" Social History 32: 133-165.

Webb, Chris. 2017. "Between Precarity and Paternalism: Farm Workers and Trade Unions in South Africa's Western Cape Province.” Global Labour Journal 8 (1): 49-64.

Wood, Ellen. 2009. "Capitalism and Social Rights." Solidarity 140. 